\title{
A PSZICHOMETRIAI KREATIVITÁS ALAKULÁSA GIMNAZISTÁK KÖRÉBEN VÉGZETT NÉGY ÉV IDŐTARTAMÚ LONGITUDINÁLIS VIZSGÁLATBAN
}

Szerzők:

Mező Katalin

Debreceni Egyetem
Lektorok:

Tóth László

Debreceni Egyetem

H. Tóth István

Károly Egyetem (Csehország)

Schéder Veronika

Debreceni Egyetem

Szerző e-mail címe:

Márton Sándor

Debreceni Egyetem

Mező Katalin (2015): A pszichometriai kreativitás alakulása gimnazisták körében végzett négy év időtartamú longitudinális vizsgálatban, Különleges Bánásmód, I. évf. 2015/1. szám, 41-53. DOI 10.18458/KB.2015.1.41

\begin{abstract}
Absztrakt
E tanulmányban a pszichometriai kreativitástesztek teszt-reteszt megbízhatóságát és intelligenciával való kapcsolatát elemezzük. Minta: $n=107$ (66 férfi, 41 nö) gimnazista. Módszer: 2011-ben felvettük a verbális Szokatlan használat és a figurális Körök kreativitásteszteket és (kiegészítö vizsgálatként) az APM intelligenciatesztet, majd 2014-ben e vizsgálatokat megismételtük. Eredmények:a kreativitásvizsgáló eljárások esetében hasonlóan mérsékelt együttjárásokat tapasztaltunk $\left(r_{s}=0,30-0,51\right)$, mint az intelligencia-vizsgálat esetében $(r=0,53)$. Az elövizsgálatok során magasabb pontszámokat szerzö tanulók inkább érnek el nagyobb pontszámkülönbséget az elö-és utótesztben, mint az elövizsgálatban alacsonyabb pontszámot szerző tanulók $\left(r_{s}=0,28-0,57\right)$.
\end{abstract}

Kulcsszavak: a kreativitás időbeli aspektusai, pszichometriai kreativitás, longitudinális vizsgálat

Diszciplinák: pszichológia, pedagógia

\begin{abstract}
THE SHAPING OF PSYCHOMETRIC CREATIVITY AMONGST SECONDAY GRAMMAR SCHOOL STUDENTS IN A FOUR YEAR LONGITUDINAL STUDY

In this study we analyse the test-retest reliabilty of psychometric creativity tests and its connection with intelligence. Sample: $n=107$ (males: 66; females: 41) secondary grammar school students. Method: in the year 2011 we applied the verbal Unusual Uses and the figural Circles creativity tests, and (as an additional test) the APM intelligence test, and we repeated these examinations in 2014. Results: there are moderate correlations between pre- and
\end{abstract}


posttests (after four years) in the cases of creativity tests $\left(r_{s}=0,30-0,51\right)$ and intelligence test $(r=0,53)$, too. The students with higher pre-test scores will probably have higher score differences between pre-and post-test than the students with lower pre-test scores $\left(r_{s}=0,28\right.$ $0,57)$.

Keywords: temporal aspects of creativity, psychometric creativity, longitudinal study

Disciplines: psychology, pedagogy

Tanulmányunkban a pszichometriai kreativitás időbeli alakulását elemezzük egy gimnazisták körében végzett négy év időtartamú longitudinális vizsgálat eredményei alapján. A kreativitás időbeliségének vizsgálatával foglalkozó hazai kutatások száma, viszonylag szerény - holott mint Runco (1999) arra rámutatott: az alkotások létrejötte tekintetében kevés fontosabb faktor van, mint maga az idő, mégsem léteznek olyan áttekintések vagy metaanalízisek, amelyek középpontjában az idő kreativitásban játszott szerepe állna. Ennek a kutatási résnek a betöltéséhez járulhatnak hozzá a tanulmány kutatási tapasztalatai is.

A kreativitás időbeliségét különböző időtávlatok és diszciplinák nézőpontjából vizsgálhatjuk: a legtágabb időtávlatot a filogenetikai, evolúciós pszichológiai megközelítés képviseli, ami az emberré válástól napjainkig terjedő időtávlatban archeológiai, antropológiai kutatásokra is építhet (Bereczkei, 2003), s vizsgálata tárgyául a kreatív képességek, teljesítmények megjelenését és evolúciós hasznát állítja. Szükebb, de időperspektívájukat tekintve nagyléptékü vizsgálatok közé sorolhatók az intergenerációs változásokra fókuszáló kreativitáskutatások is. Ilyen például Kim (2011) metaanalízise, melyben az 1966 és 2008 közötti időszakot figyelembe véve tanulmányozza $(n=272599)$ az egyes generációk kreativitás pontszámainak alakulását.

Az ontogenetikai és fejlődéslélektani orientációjú kutatók egy emberélet távlatában vizsgálják a kreativitás alakulását (Siegelman és Rider, 2006), s életrajzokra, interjúkra, teljesítményekre támaszkodó életútelemzéseket is alkalmazhatnak a teszteléses, kérdőíves jellegü longitudinális és transzverzális adatgyüjtések mellett (Tóth, 2011). A pszichometriai kreativitást tekintve több kutató (például Kim, 2011; Timmel, 2001; Marcon, 1995; Kang, 1989; Smith és Carlsson, 1983; Torrance, 1977) is érinti a témát.

A kreatív folyamatra fókuszáló elméletalkotók egy probléma észlelésétől a megoldásig (vagy akár széleskörü terjesztésig) terjedő távlatban gondolkodnak (Zétényi, 2010). Ennek a megközelítésnek a speciális esetét jelentik az ezredmásodpercek alatt lezajló kognitív folyamatokra koncentráló kutatások (Zétényi, 2008), illetve a kifejezetten a kreatív feladatok közben észlelhető agyi elektromos jelenségekre fókuszáló kutatások (Razumnikova, Tarasova és Vol'f, 2009; Razumnikova, 2009).

Végül, egy vagy több tesztfelvétel időtartamát, illetve a köztük eltelt időtartamot vehetik figyelembe a pszichometriai kreativitás iránt érdeklődők. A rögzített idői keretek között müködő ún. „sebességtesztek” (szemben az „erőtesztekkel”, melyekben a feladatok megoldási ideje nincs korlátozva - Zétényi, 2008) hátterében az áll, hogy a személyekre jellemző lehet kognitív folyamataik időbelisége (például müveleti sebességük), s a kutatások ezek hatásait vizsgálják.

Ebbe az utóbbi megközelítési módba sorolhatjuk jelen kutatásunkat is, melyben a kreativitástesztekben elért pontszámok időbeli aspektusait elemezzük a Torrance Tests of Creative Thinking (TTCT) hazai adaptációiban (Zétényi, 1989) nyújtott eredmények alapján; így a következőkben e tesztekre irányuló kutatási tapasztalatokra fókuszálunk. 


\section{Longitudinális kreativitáskutatások}

A kreatív képességek ontogenetikus változásainak értelmezéséhez a longitudinális és a transzverzális kutatások eredményei szolgáltathatnak támpontokat. A kreativitás vizsgálatára irányuló leghosszabb időtartamú longitudinális vizsgálatok a life span (életút-elemző jellegű) kutatások (Alpaugh és Birren, 1977; Romaniuk és Romaniuk, 1981; Csíkszentmihályi, 1996), melyekben akár egész élethosszra kiterjedő eredményeket elemeznek. Emellett, számos olyan jelentős időintervallumot átívelő (több évtizedet felölelő) kreativitáskutatással találkozhatunk, melyeknek alapjait a Torrance-féle TCT tesztek szolgáltatják. A TTCT önmagában is, az egyik legjelentősebb nyomonkövetési szisztémával rendelkező eljárás. A longitudinális vizsgálat bázisát Torrance 1958-ban végzett kutatási eredményei szolgáltatják; majd kutatási beszámolók jelentek meg elöször 22 év (Torrance, 1980, 1981a, 1981b), majd 40 év (Cramond és társai, 2005) és később 50 év (Runco és társai, 2011) távlatában történt utótesztelés alapján.

Nemzetközi longitudinális vizsgálatokat összefoglaló kiadvány jelent meg Runco (1999) szerkesztésében, melyben például Helson (1999) mintegy 100 nő esetében 30 éves távlatban (20-50 éves kor között) vizsgálta a nők kreatív potenciáljának változását. Tapasztalatai szerint a kreatív vonások erős konzisztenciát mutattak a korábbi vizsgálatokkal, de az egyének kreatív vitalitása fluktuált az élethelyzetek változásainak függvényében. Plucker (1999) 212 fö, 3-5. évfolyamos diák 1958-1965 közötti időszakban Torrance által felvett TTCT tesztjeit és IQ pontszámait vetette össze az átlagosan 22 évvel későbbi kreatív teljesítményeikkel. Ennek a vizsgálatnak az eredményei alátámasztják a TTCT prediktív validitását, s arra engednek következtetni, hogy a divergens gondolkodást jellemző pontszámok jobb elörejelzői a felnőttkori kreatív teljesítményeknek, mint az intelligencia.

Hazai longitudinális kreativitáskutatásról szóló beszámolók szórványosan jelentek meg és rövidebb időtartamot ölelnek fel. Nézzünk ezekre is néhány példát:

Kürti (1978) 1-4. évfolyam között végzett longitudinális vizsgálatában az originalitás stagnálásáról, s a fluencia, illetve flexibilitás mutató fejlődéséről számolt be. Majd egy későbbi vizsgálatában (Kürti, 1982) - ahol 9-14 évesek konvergens és (TTCT-vel mért) divergens képességeinek életkori alakulását és ennek hátterében álló intra- és extrapszichikus tényezőit vizsgálta - többek között azt tapasztalta, hogy a többszörös lineáris regresszió szerint a fluencia önmagában az összkreativitás varianciájának kb. 70\%-át magyarázza minden egyes életkorban. Az életkor előrehaladásával a flexibilitás és az originalitás szerepe is nő, ezt a tapasztalatot támasztja alá Ceglédi (2009) kétéves longitudinális vizsgálata is.

Győri (1986) 1-8. évfolyamon végzett komplex gondolkodásfejlődést érintő kutatást ( $n=$ 40), melyben a divergens gondolkodás is éves rendszerességgel felmérésre került. Eredményei szerint a divergens gondolkodás fejlődése egyenletesebb görbével jellemezhető, mint az a tranzverzális kutatások terén tapasztalható - Salamon tranzverzális (Salamon, 1982) és longitudinális (Salamon, 1992) eredményei is megerősítik ezt.

Jelen vizsgálatban egy négy éves időtartamot felölelö longitudinális kutatás eredményeit mutatjuk be, melynek során az elöször 2011-ben, majd 2014-ben felvett kreativitástesztek vizsgálati eredményeit hasonlítottuk össze. A vizsgálatban a hazai kreativitástesztek mutatóinak időbeli stabilitására voltunk kíváncsiak. Emellett a pszichometriai kreativitás, az intelligencia és a nemek kapcsolatára, valamint időbeli aspektusaira vonatkozó elemzéseket is végeztünk.

\section{Kérdések}

Mindenekelőtt arra voltunk kíváncsiak, hogy milyen mértékben képesek bejósolni a 2011ben nyújtott teljesítmények a 2014-ben nyújtott eredményeket? Azaz időbeli állandóságot vagy változékonyságot tapasztalunk a kreativitásmutatók tekintetében? Hipotézisünk meg- 
alkotásában Torrance (2002) vizsgálatainak eredményeire támaszkodtunk, melyekben nem túl erős (a tesztfelvétel után 12 évvel $r=0,27-0,51$ közötti; a tesztfelvétel után 22 illetve 40 évvel $r=0,38-0,58$ körüli) korrelációk vannak. Ehhez hasonló értékek jelentek meg Plucker (2000) vizsgálatában is. Mindezekböl kiindulva úgy véljük, hogy az első vizsgálatban nyújtott teljesítmények képesek bejósolni a kimeneti vizsgálatban nyújtott eredményeket, azaz a kreativitásmutatók időben statikusak.

Következő kérdésünkben a kreativitásteszt változóinak egymás közötti összefüggéseire fókuszáltunk. Arra kérdeztünk rá, hogy az első vizsgálatban jobb eredményt elérők jobb teljesítményt fognak-e mutatni a 2014-ben kitöltött tesztekben is; illetve, hogy azok a tanulók, akik az első vizsgálat alkalmával még alacsonyabb eredményeket értek el, képesek-e utolérni társaikat? Véleményünk szerint, az első vizsgálatban jobb teljesítményt nyújtók, a második vizsgálat alkalmával is jobb eredményt fognak nyújtani a társaiknál, s az első vizsgálatban gyengébb eredményeket elérők pedig nem érik utol a társaikat (v.ö. Barkóczi (1976) vizsgálatával, aki azt találta, hogy a kreativitástesztben jobb eredményt elérő felvételizők egyetemi pályafutása eredményesebb volt társaikénál).

Ezt követően a kreativitástesztekben és az intelligenciatesztekben nyújtott teljesítmények egymásra gyakorolt hatására vonatkozó kérdést tettünk fel: arra kerestük a választ, hogy milyen hatásai vannak az intelligenciabeli különbségeknek a kreativitástesztbeli teljesítményekre? Feltételezzük, hogy az intelligencia tesztben magasabb pontszámot elérők, jobb teljesítményt fognak nyújtani mindkét kreativitás tesztben.

Végül kérdésként merült fel, hogy van-e különbség a lányok és a fiúk kreativitástesztekben nyújtott teljesítményében, és ha van különbség az megmarad-e az életkor előrehaladásával? Cambell (1960) és Simonton (2004) kutatásaira alapozva feltételezzük, hogy különbséget fogunk tapasztalni a lányok és a fiúk kreativitás tesztekben nyújtott teljesítménye terén, feltételezhetően a verbális kreativitás feladatokban a lányok lesznek eredményesebbek, a figurális feladatokban pedig a fiúk; és ez a különbség megmarad az életkor elörehaladásával.

\section{Minta}

A vizsgálati mintát középiskolai tanulmányaikat 2011-ben 9. évfolyamon megkezdö és 2014-ben 12. évfolyamon befejező tanulók alkotják ( $n=107 ; 66$ férfi, 41 nő). Átlagos életkoruk a 2011-es elővizsgálat idején 14,68 év ( $S D=0,49$ év), a legfiatalabb vizsgálati személy 14, a legidősebb 16 éves volt. A vizsgálatban való részvétel önkéntes és anonim, a szülők által írásban engedélyezett volt.

\section{Módszer}

2011-ben (a továbbiakban: az „első vizsgálat”-ként, „,bemeneti vizsgálat”-ként, illetve „9. évfolyamos korban végzett vizsgálat"-ként is fogunk még erre az adatgyüjtési alkalomra hivatkozni) 9. évfolyamos vizsgálati személyekkel felvettük a Szokatlan használat és a Körök kreativitásteszteket és kiegészítő vizsgálatként az APM intelligenciatesztet használtuk. E vizsgálatokat ismételten elvégeztük 2014-ben (a továbbiakban: „második vizsgálat”-ként, „kimeneti vizsgálat”-ként, illetve „12. évfolyamos korban végzett vizsgálat”-ként is fogunk még erre az adatgyüjtési alkalomra hivatkozni) az akkor már 12. évfolyamon tanuló vizsgálati személyekkel. A kreativitástesztek értékelésekor a Zétényi (1989) által közreadott sztenderdet követtük, s a fluencia, originalitás, flexibilitás, átlagos originalitás, relatív flexibilitás mutatókat számoltuk ki. Az APM teszt értékelésekor a nyerspontokat számítottuk ki a teszt útmutatójában (Raven, 1969) leírtaknak megfelelően (minden helyes válasz 1 pontot ért). A Körök teszt esetében lehetőséget adtunk arra, hogy a vizsgálati személyek további köröket is rajzolhassanak, amennyiben az előre nyomtatottakat már mind felhasználták. 
Ennek az eljárásnak megfelelően minden vizsgálati személy esetében rendelkezésre álltak a 2011. és a 2014. évben mért Zétényi-féle értékelő táblázat felhasználásával számított kreativitásteszt eredmények, illetve az APM-teszt, s a tanulás iránti attitüd kérdőív eredményei (ez utóbbit jelen vizsgálatban csak egy demonstráció során használunk fel).

A változók normalitásának (Kolmogorov-Smirnov-próba révén történő) ellenőrzését követően részben paraméteres matematikai statisztikai próbákkal vizsgálatuk a különbségeket, illetve az együtt járásokat. A matematikai statisztikai számításokat az SPSS 13.0 for Windows szoftverrel végeztük.

\section{Eredmények}

A Kolmogorov-Smirnov-próba eredménye szerint vizsgálati változóink közül egyedül a Körök teszt első vizsgálatban mért flexibilitás változója nem normális eloszlású, a többi változónk eloszlása azonban nem tér el szignifikánsan a normálistól. Ennek megfelelően a továbbiakban paraméteres statisztikai próbákat alkalmazunk a normális eloszlást követő változók esetében illetve nem paraméteres statisztikai teszteket használunk az említett nem normális eloszlású változó esetében.

$\mathrm{Az}$ 1. táblázat foglalja össze a leíró statisztikai eredményeket, valamint az elö- és utóvizsgálat közötti különbségek vizsgálatára alkalmazott páros t-próba, illetve páros wilcoxon-féle előjeles rangpróba eredményeit. A tanulók pontszáma szignifikánsan $(|M D|=$ 1,48-3,62; $p \leq 0,05 ;)$ növekedett a verbális kreativitásteszt fluencia, originalitás, flexibilitás mutatóiban, a figurális kreativitásteszt fluencia mutatóiban és az intelligenciavizsgálat nyerspontszámában. Szignifikáns, bár csekély értékü $(M D=0,05 ; p \leq 0,05)$ pontszám csökkenés mutatkozott a verbális kreativitásteszt relatív flexibilitás mutatójában és a Körök teszt flexibilitás mutatójában. A többi mutatóban nem tapasztaltunk szignifikáns változást.

A vizsgálati személyek által először 2011-ben, majd 2014-ben kitöltött kreativitástesztek közötti ( $r$ korrelációs együtthatóval jelölt) Pearson-féle és ( $r_{s}$ együtthatóval jelölt) Spearmanféle korrelációk alakulása (2. táblázat):

- A fluencia tekintetében szignifikáns pozitív irányú, mérsékelt korrelációkat tapasztaltunk (szokatlan használat teszt: $r=0,397$; körök teszt: $r=0,506$; mindkét teszt esetében $p \leq 0,01)$.

- Az originalitással kapcsolatban a szokatlan használat teszt esetében $r=0,354$; a körök tesztben pedig $r=0,486$ értékü szignifikáns $(p \leq 0,01)$ együtt járást kaptunk. Az átlagos originalitást tekintve azonban nem tapasztaltunk szignifikáns korrelációt egyik teszt esetében sem.

- A flexibilitás pontszámok közötti korreláció a Szokatlan használat teszt esetében $r=$ 0,304 (a relatív flexibilitás értéke pedig: $r=0,338$ ); a körök teszt esetében $r_{s}=0,317$ $(p \leq 0,01)$. A figurális teszt relatív flexibilitás mutatójának első és második mérés során nyert pontszámai nem mutatnak szignifikáns együtt járást.

Az intelligencia mérésére használt APM intelligenciateszt 9. és 12. évfolyamos korban elért nyerspontszámai között mérsékelt, pozitív irányú együtt járást találtunk $(r=0,528 ; p \leq 0,01)$.

Kérdés, hogy a 2. táblázatban összefoglalt pozitív együtt járások hátterében vajon az eleve magasabb pontszámot elérő tanulók játszanak-e nagyobb szerepet, (vagyis: pozitív korreláció van-e az első vizsgálat és az ahhoz képest a kimeneti vizsgálatig elért pontszámnövekedés között), vagy az első vizsgálat során gyengébb tanulóktól várható nagyobb fejlődés (vagyis negatív korrelációt tapasztalhatunk-e a bementi vizsgálat és az ahhoz képest a kimeneti vizsgálatig elért pontszámnövekedés között), vagy nem mutatható ki lineáris kapcsolat az első vizsgálatban elért pontszám és az kimeneti vizsgálatig elért pontszámnövekedés között. A kérdés megválaszolása érdekében kiszámoltuk a bemeneti és a kimeneti különbségváltozók értékeit, majd Kolmogov-Smirnov-próbával ellenőriztük e különbségváltozók normális elosz- 
1. táblázat: leíró statisztika és normalitásvizsgálat eredményeinek összefoglalása. (forrás: Szerzö)

\begin{tabular}{|c|c|c|c|c|c|c|c|c|c|c|c|}
\hline \multirow[b]{2}{*}{ Teszt } & \multirow[b]{2}{*}{ Változó } & \multirow[b]{2}{*}{ Vizsgálat } & \multirow[b]{2}{*}{ Átlag } & \multirow[b]{2}{*}{ Szórás } & \multirow{2}{*}{$\begin{array}{c}\text { Átlagok } \\
\text { különbsége }\end{array}$} & \multirow[b]{2}{*}{ Minimum } & \multirow[b]{2}{*}{ Maximum } & \multicolumn{3}{|c|}{ Percentilisek } & \multirow[b]{2}{*}{ t } \\
\hline & & & & & & & & $25 \%$ & $\begin{array}{c}\mathbf{5 0 \%} \\
\text { (medián) }\end{array}$ & $75 \%$ & \\
\hline \multirow{10}{*}{ 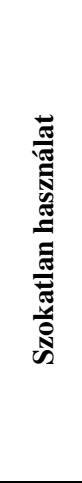 } & \multirow{2}{*}{ Fluencia } & elővizsgálat & 12,88 & 6,29 & \multirow{2}{*}{$-3,48$} & 3,00 & 30,00 & 8,25 & 11,50 & 17,00 & \multirow{2}{*}{$-4,88 *$} \\
\hline & & utóvizsgálat & 16,49 & 5,56 & & 5,00 & 38,00 & 12,50 & 16,00 & 20,00 & \\
\hline & \multirow{2}{*}{ Originalitás } & elővizsgálat & 6,80 & 3,60 & \multirow{2}{*}{$-1,48$} & 0,80 & 16,79 & 4,28 & 6,14 & 8,81 & \multirow{2}{*}{$-3,59 *$} \\
\hline & & utóvizsgálat & 8,38 & 2,99 & & 2,98 & 19,11 & 6,34 & 8,42 & 9,97 & \\
\hline & \multirow{2}{*}{ Flexibilitás } & elővizsgálat & 9,58 & 3,85 & \multirow{2}{*}{$-2,05$} & 3,00 & 19,00 & 7,00 & 9,00 & 12,00 & \multirow{2}{*}{$-4,52^{*}$} \\
\hline & & utóvizsgálat & 11,77 & 3,10 & & 4,00 & 21,00 & 9,50 & 12,00 & 14,00 & \\
\hline & \multirow{2}{*}{$\begin{array}{l}\text { Átlagos } \\
\text { originalitás }\end{array}$} & elővizsgálat & 0,53 & 0,09 & \multirow{2}{*}{0,02} & 0,27 & 0,81 & 0,48 & 0,52 & 0,58 & \multirow{2}{*}{ n.s. } \\
\hline & & utóvizsgálat & 0,51 & 0,06 & & 0,36 & 0,66 & 0,47 & 0,50 & 0,54 & \\
\hline & \multirow{2}{*}{$\begin{array}{l}\text { Relatív } \\
\text { flexibilitás }\end{array}$} & elővizsgálat & 0,79 & 0,15 & \multirow{2}{*}{0,05} & 0,39 & 1,00 & 0,67 & 0,80 & 0,91 & \multirow{2}{*}{$-2,91 *$} \\
\hline & & utóvizsgálat & 0,74 & 0,12 & & 0,42 & 1,00 & 0,65 & 0,73 & 0,82 & \\
\hline \multirow{10}{*}{ 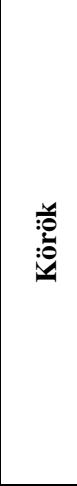 } & \multirow{2}{*}{ Fluencia } & elővizsgálat & 18,57 & 5,77 & \multirow{2}{*}{$-1,93$} & 4,00 & 37,00 & 14,50 & 18,00 & 22,00 & \multirow{2}{*}{$-2,26 *$} \\
\hline & & utóvizsgálat & 20,58 & 9,01 & & 2,00 & 70,00 & 15,00 & 20,00 & 25,00 & \\
\hline & \multirow{2}{*}{ Originalitás } & elővizsgálat & 8,69 & 3,39 & -0.24 & 1,90 & 18,39 & 6,07 & 8,40 & 11,24 & \\
\hline & & utóvizsgálat & 9,02 & 3,72 & $-0,24$ & 0,79 & 21,24 & 6,13 & 8,91 & 11,04 & n.s. \\
\hline & Flexil & elővizsgálat & 10,10 & 2,85 & & 3,00 & 16,00 & 8,00 & 11,00 & 12,00 & \\
\hline & Fiexiomintas & utóvizsgálat & 10,84 & 3,35 & $-0, / 2$ & 2,00 & 18,00 & 8,50 & 11,00 & 13,00 & 11.s. \\
\hline & Átlagos & elővizsgálat & 0,47 & 0,12 & 0.02 & 0,12 & 0,68 & 0,42 & 0,48 & 0,54 & $n s$ \\
\hline & originalitás & utóvizsgálat & 0,45 & 0,10 & & 0,18 & 0,76 & 0,40 & 0,47 & 0,51 & 11.s. \\
\hline & Relatív & elővizsgálat & 0,57 & 0,15 & & 0,19 & 1,00 & 0,48 & 0,58 & 0,67 & \\
\hline & & utóvizsgálat & 0,57 & 0,15 & & 0,20 & 1,00 & 0,46 & 0,56 & 0,67 & n.s. \\
\hline & Nyer: & elővizsgálat & 33,19 & 4,75 & & 19,00 & 45,00 & 31,00 & 34,00 & 36,00 & $196 *$ \\
\hline & & utóvizsgálat & 36,92 & 4,61 & $-5,02$ & 21,00 & 47,00 & 34,00 & 38,00 & 40,00 & \\
\hline
\end{tabular}

*Páros t-próba szignifikáncia szintje: $\boldsymbol{p} \leq \mathbf{0 , 0 5}$

**Páros Wilcoxon-féle előjeles rangpróba eredménye (nem t-érték)

2. táblázat: 9., majd 12. évfolyamos korban nyújtott teszteredmények közötti korreláció (forrás: Szerzö)

\begin{tabular}{llllll}
\hline Teszt & Fluencia & Originalitás & Flexibilitás & Átlagos originalitás & Relatív flexibilitás \\
\hline Szokatlan használat & 0,397 & 0,354 & 0,304 & n.s. & 0,338 \\
Körök & 0,506 & 0,486 & $0,317 *$ & n.s. & n.s. \\
\hline *A Körök teszt flexibilitás változója esetében Spearman-féle $\left(\boldsymbol{r}_{\boldsymbol{s}}\right)$ rangkorrelációt, a többi esetben Pearson-féle $(\boldsymbol{r})$ korrelációt jelölnek
\end{tabular}

a számok. Minden esetben: $\boldsymbol{p} \leq \mathbf{0 , 0 1}$. n.s. = nem szignifikáns korreláció

lását. Mivel közülük többre is jellemző volt, hogy nem normális eloszlásúak, ezért Spearmanféle rangkorreláció számítást végeztünk, melynek eredményeit a 3. táblázat összegzi. A pszichometriai intelligenciát tekintve az APM bemeneti pontszám és az elért APMpontszámkülönbség között mérsékelt együtt járás tapasztalható $\left(r_{s}=0,354 ; p<=0,05\right)$. A tanulók által a bemeneti vizsgálat során elért APM pontszám és a kreativitás mutatók között nem tapasztalható szignifikáns lineáris kapcsolat (kivéve a figurális teszt ötletgazdagságot tükröző fluencia különbségváltozóját, mellyel $r_{s}=-0,240 ; p \leq 0,05$ értékekkel jellemezhető kapcsolatban áll a 9. évfolyamon mért APM nyerspontszám). 
3. táblázat: a 9. évfolyamon elért pontszámok és az ezekhez képest a 12. évfolyamra elért pontszámkülönbségek közötti rangkorrelációk (forrás: Szerzö)

\begin{tabular}{llllll}
\hline Teszt & Fluencia & Originalitás & Flexibilitás & Átlagos originalitás & Relatív flexibilitás \\
\hline Szokatlan & 0,511 & 0,565 & 0,568 & 0,560 & 0,557 \\
használat & n.s. & 0,276 & 0,309 & 0,502 & 0,448 \\
Körök & * A cellákban lévó értékek $\boldsymbol{p} \leq \mathbf{0 , 0 5}$ szinten szignifikáns Spearman-féle $\left(\boldsymbol{r}_{\mathrm{s}}\right.$ ) rangkorrelációk; n.s. = nem szignifikáns korreláció
\end{tabular}

* A cellákban lévő értékek $p \leq 0,05$ szinten szignifikáns Spearman-féle $\left(r_{s}\right)$ rangkorrelációk; n.s. = nem szignifikáns korreláció

$\mathrm{Az}$ adatelemzés következő lépéseként Spearman-féle rangkorreláció számítással azt is teszteltuik, hogy: a) egy kreativitásteszt mutatóiban a két különböző időpontban történt mérésből számolt pontszámkülönbségek pozitív korrelációs kapcsolatban állnak-e egymással; b) a két különböző kreativitásteszt mutatóinak pontszámkülönbségei is pozitív együtt járást mutatnak-e; c) a kreativitástesztekben nagyobb pontszámkülönbséget elérö tanulók az intelligenciatesztben is nagyobb pontszámkülönbséget érnek-e el. A pontszámkülönbségek rangkorrelációit a 4. táblázat foglalja össze.

4. táblázat: a 9. és a 12. évfolyamos korban végzett vizsgálatok pontszámkülönbségei közötti Spearman-féle rangkorrelációk (forrás: a Szerzö)

\begin{tabular}{|c|c|c|c|c|c|c|c|c|c|c|c|}
\hline \multirow{2}{*}{ Teszt } & \multirow{2}{*}{ Mutató } & \multicolumn{5}{|c|}{ Szokatlan használat teszt } & \multicolumn{5}{|c|}{ Körök teszt } \\
\hline & & $\mathbf{K}_{\mathbf{F}}$ & $\mathbf{K}_{\mathbf{O}}$ & $\mathbf{K}_{\mathbf{X}}$ & $\mathbf{K}_{\mathbf{A} \mathbf{O}}$ & $K_{\mathrm{RX}}$ & $\mathbf{K}_{\mathbf{F}}$ & $\mathbf{K}_{\mathbf{O}}$ & $\mathbf{K}_{\mathbf{X}}$ & $\mathbf{K}_{\mathbf{A} \mathbf{O}}$ & $\mathbf{K}_{\mathrm{RX}}$ \\
\hline \multirow{5}{*}{$\begin{array}{l}\text { Szokatlan } \\
\text { használat }\end{array}$} & $\mathbf{K}_{\mathbf{F}}$ & 1,000 & 0,965 & 0,920 & 0,468 & n.s. & 0,596 & 0,635 & 0,576 & 0,461 & 0,335 \\
\hline & $\mathbf{K}_{\mathbf{O}}$ & & 1,000 & 0,907 & 0,607 & n.s. & 0,597 & 0,636 & 0,569 & 0,411 & 0,307 \\
\hline & $\mathbf{K}_{\mathbf{X}}$ & & & 1,000 & 0,513 & 0,328 & 0,577 & 0,632 & 0,569 & 0,502 & 0,349 \\
\hline & $\mathbf{K}_{\text {ÁO }}$ & & & & 1,000 & 0,533 & 0,499 & 0,493 & 0,493 & 0,365 & 0,420 \\
\hline & $K_{\mathrm{RX}}$ & & & & & 1,000 & 0,403 & 0,359 & 0,348 & 0,405 & 0,385 \\
\hline \multirow{5}{*}{ Körök } & $\mathbf{K}_{\mathbf{F}}$ & & & & & & 1,000 & 0,828 & 0,738 & 0,296 & n.s. \\
\hline & $\mathbf{K}_{\mathbf{O}}$ & & & & & & & 1,000 & 0,837 & 0,665 & 0,365 \\
\hline & $\mathbf{K}_{\mathbf{X}}$ & & & & & & & & 1,000 & 0,592 & 0,624 \\
\hline & $\mathbf{K}_{\mathbf{A} O}$ & & & & & & & & & 1,000 & 0,728 \\
\hline & $K_{\mathrm{RX}}$ & & & & & & & & & & 1,000 \\
\hline APM & $K_{\text {NYP }}$ & 0,315 & 0,251 & 0,336 & n.s. & 0,294 & 0,281 & 0,298 & 0,357 & 0,393 & 0,380 \\
\hline
\end{tabular}

Magyarázat: $\mathrm{K}_{\mathrm{F}}=$ fluencia pontszám különbségek, $\mathrm{K}_{\mathrm{O}}=$ originalitás pontszámok különbsége, $\mathrm{K}_{\mathrm{X}}=$ flexibilitás pontszámok különbsége, $\mathrm{K}_{\hat{A} \mathrm{O}}=$ átlagos originalitás pontszámok különbsége, $\mathrm{K}_{\mathrm{RX}}=$ relatív flexibilitás pontszámok különbsége, $\mathrm{K}_{\mathrm{NYP}}=$ Nyerspontok különbsége; n.s. = nem szignifikáns. A cellákban látható számok $p$ $\leq 0,05$ szinten szignifikáns rangkorrelációs értékek.

Az intelligenciabeli különbségek kreativitástesztbeli pontszámokra gyakorolt hatásának feltárása érdekében Mann-Whitney-féle U-próbát is végeztünk, melynek eredménye szerint egyedül a Körök teszt relatív flexibilitás mutatójának különbségváltozója mentén van szignifikáns különbség az APM elővizsgálatban alacsony (medián alatti) és magas (medián feletti) pontszámot elérő tanulók között az utóbbiak javára $(U=849,500 ; Z=-2,173 ; p \leq 0,05)$; a többi kreativitásmutató tekintetében azonban nem találtunk szignifikáns különbséget.

A normális eloszlású változók esetében varianciaanalízissel vizsgáltuk a nemek és az elővizsgálatban alacsony/magas APM pontszámú csoportba tartozás kreativitásmutatókra gyakorolt önálló hatását, illetve interakciójukat, ám szignifikáns hatásokat nem találtunk.

A nemek közötti különbségeket tekintve a független mintás t-próba eredményei szerint, a verbális kreativitásvizsgálat és az intelligenciavizsgálat esetében nincs szignifikáns különbség a nemek között; a Körök teszt kimeneti vizsgálatában azonban az originalitás $(t=-2,518 ; M D$ 
$=-1,9223)$, a flexibilitás $(t=-3,173 ; M D=-2,142)$ és az átlagos originalitás $(t=-2,585 ; M D=$ $-0,05041)$ terén a lányok szignifikánsan $(p \leq 0,05)$ magasabb pontszámot értek el, mint a fiúk. A Mann-Whitney-féle U-próba eredménye szerint a Körök tesztben az első vizsgálat alkalmával a lányok flexibilitás pontszáma magasabb volt, mint a fiú tanulóké ( $U=900,500 ; Z=-$ $2,169 ; p \leq 0,05)$. A Körök teszt többi változójában nincs szignifikáns nemek közötti különbség.

\section{Megvitatás}

A tanulók által a 9. és 12. évfolyamos korukban elért pontszámokat összehasonlítva különbségeket tapasztalhatunk a verbális és a figurális kreativitás között (1. táblázat). Úgy tünik, hogy a verbális kreativitás a fluencia, originalitás és flexibilitás terén nagyobb időbeli változékonyságot (itt: pontszámnövekedésben kimutatható fejlödést) mutat a vizsgált 14-18 év körüli életkorban, mint az időben statikusabbnak tekinthetö figurális kreativitás. Így csak a

figurális Körök Teszt esetében nyert alátámasztást az a feltevésünk, mely szerint az első vizsgálatban nyújtott teljesítmények képesek bejósolni a kimeneti vizsgálatban nyújtott eredményeket. Vizsgálatunk alapján a Körök teszt prediktív érvényessége jobbnak bizonyult a Szokatlan Használat tesztnél.

Noha a leíró statisztikai eredmények és a bemeneti és kimeneti mérések közötti különbségvizsgálatok önmagukban is elgondolkodtató tehetségdiagnosztikai jelentőséggel bírhatnak, e különbségvizsgálatok azonban nem képesek rámutatni számszerüen arra, hogy vajon a két mérési alkalom közötti különbségek/hasonlóságok mögött milyen együtt járások mutathatók ki. Például a kezdeti mérésben eleve jobb eredményt elérők fognak-e a második vizsgálat során is jobban teljesíteni, vagy pedig azok a tanulók érik utol társaikat, akik az első vizsgálat alkalmával még alacsonyabb eredményt értek el. Ezért a bemeneti és a kimeneti vizsgálat eredményei közötti korrelációs kapcsolatot is ellenőriztük.

Eredményeink szerint (lásd: 2. táblázat) a 9., majd 12. évfolyamos korban szerzett fluencia, originalitás és flexibilitás pontszámok a verbális és a nem verbális kreativitás teszt esetében is szignifikáns pozitív irányú, bár mérsékelt jellegü ( $r=0,304-0,506 ; p \leq 0,01)$ korrelációs kapcsolatban állnak egymással (hasonló tapasztalatokról számol be Torrance, 1966 is). Cronbach (1951) alapján százalékos értékekre fordítva ezeket a korrelációkat, négy év távlatában kb. 9-25\%-os valószínüséggel fognak jobb eredményeket elérni e kreativitásmutatókban azok, akik az első vizsgálat alkalmával is jobb eredményeket értek el. Ez az eredmény - amellett, hogy mérsékelt teszt-reteszt megbízhatóságot tükröz egy közel négy éves időintervallum esetében - nem bátoríthat bennünket határozott predikciók megtételére, amikor egy 9. évfolyamon végzett (például tehetséggondozó programba történő beválogató) kreativitás vizsgálat eredményeire alapozva szeretnénk bejósolni (a speciális kreativitásfejlesztésben nem részesülö) gimnazisták 12. évfolyamos korban mérhető pontszámait. Fejlödéslélektani szempontból az eredményeket úgy is értelmezhetjük, hogy a pszichometriai kreativitás 14 éves kor körül mérhető alacsony/magas fluencia, originalitás és flexibilitás pontszámai a pubertáskor végén mért alacsony/magas értékekkel mutatnak ugyan némi együtt járást, de ez a mérsékelt együtt járás igen esetleges.

A fluencia pontszámnövelö hatását redukálni törekvő változók tekintetében azt tapasztaltuk, hogy a 9. és 12. évfolyamos korban felvett kreativitástesztek átlagos originalitás pontszámai egyik kreativitásteszt esetében sem korreláltak egymással; a relatív flexibilitás esetében pedig csak a verbális kreativitás tesztnél figyelhettünk meg mérsékelt, pozitív irányú korrelációt $(r=$ $0,338 ; p \leq 0,01)$. Eredményeinket általánosítva azt mondhatjuk, hogy egy diák által egy nyitott feladatra adott eredeti ötletek száma az összes ötlet számához képest igen nagy változékonyságot mutathat a pubertáskor utolsó négy évében. Hasonló a helyzet a nézőpontváltásra kész, rugalmas gondolkodás esetében is - azzal a megkötéssel, hogy a verbális feladatokban 
alig valamivel bejósolhatóbb a relatív flexibilitás alakulása, mint a figurális feladatok esetében. A vizsgálat során kapott teszt-reteszt korrelációk illeszkednek ahhoz a mások (Torrance, 1966; Zétényi, 1989; Cropley, 2000) által közölt eredményekhez, melyek szerint az ismételt mérések több éves távlatban mérsékelt korrelációt mutatnak egymással.

Spearman-féle rangkorrelációs számítással teszteltük a tanulók által az elővizsgálatban elért pontszámok és az elővizsgálattól az utóvizsgálatig elért pontszámkülönbség közötti együtt járást. Amint azt a 3. táblázat mutatja, egyedül a Körök teszt fluencia mutatója esetében nem találtunk szignifikáns korrelációt, a többi esetben a $r_{s}=0,276$ és 0,568 közötti szignifikáns ( $p$ $\leq$ 0,05) együtt járást tapasztaltunk (a rangkorrelációs együttható értéke a verbális kreativitástesztben valamivel nagyobb, mint a figurális teszt esetében). Úgy tünik, hogy többnyire azok a tanulók értek el nagyobb mértékü kreativitástesztbeli pontszámkülönbséget (fejlődést), akik eleve magasabb pontszámokat szereztek az első vizsgálat alkalmával. A korreláció mérsékelt értéke azonban nem teszi lehetővé, hogy egy személy kreatív fejlődési potenciáljának mérlegelésekor (például egy tehetséggondozó programba történő beválogatás vagy egy munkaerő kiválasztás alkalmával) kizárólag a tesztekkel aktuálisan kimutatható pontszámot vegyük figyelembe. Az eredmények szerint e fejlődési potenciál ugyanis nem becsülhető fel megbízható módon egyetlen vizsgálat révén, hiszen a 0,5 körüli korrelációk alapján mindössze 25\%-kal csökkenthető a fejlődés (elővizsgálathoz képest várható pontszámnövekedést jósló) elörejelzésének hibája. A jövőben szükség lenne (ideális esetben korosztályonkénti, de legalábbis az intézményes nevelés jellegzetes szakaszaihoz illeszkedő korcsoportonkénti) keresztmetszeti és nyomon követéses vizsgálatokkal további adatokat gyüjteni a pszichometriai kreativitás fejlődéslélektani jellemzőinek megismerése céljából. Mindezek alapján azon feltevésünk, melyben úgy véltük, hogy ,az első vizsgálatban jobb teljesítményt nyújtók, a második vizsgálat alkalmával is jobb eredményt fognak nyújtani a társaiknál, s az első vizsgálatban gyengébb eredményeket elérök pedig nem érik utol a társaikat" - igazolást nyert, viszont a mérsékelt korrelációk a jelentős (például a gyermek egyegy teszt alapján történő tehetségazonosítása típusú) döntések meghozatalában nem elégségesek.

A kreativitástesztek és az intelligenciatesztekben nyújtott teljesítmények egymásra gyakorolt hatásával kapcsolatos eredmények megvitatása: az intelligenciatesztben elért pontszámok szignifikáns növekedést mutattak a longitudinális vizsgálat időtartama alatt, ami (a Szokatlan használat teszthez viszonyítva) szintén egyfajta időbeli változékonyságot jelez a vizsgált életkorokban (1. táblázat). A tanulók pszichometriai intelligenciájának mérésére alkalmazott APM teszt elő- és utóvizsgálati eredményeit tekintve mérsékelt, pozitív irányú korrelációt kaptunk $(r=0,528 ; p \leq 0,01)$. A vizsgálatunkban tapasztalt korreláció némileg alacsonyabb, mint amelyeket az intelligenciakutatás klasszikus vizsgálataiban tapasztaltak például: Jones és Bayley, 1941; Moffit és társai, 1993; akik a tanulók 12 éves kori és 18 éves kori tesztpontszámai között erős $(r \geq 0,77)$ korrelációt találtak. Figyelemre méltó, hogy a teszt-reteszt vizsgálatok közötti korrelációk nagyságrendje igen hasonló a pszichometriai intelligencia és kreativitás esetében.

További adatelemzés érdekében teszteltük az elővizsgálat során mért intelligencia korrelációs kapcsolatát a kreativitás- és intelligenciatesztekben az utóvizsgálatig elért pontszámkülönbségekkel. Az APM elővizsgálati pontszám és az elért APM-pontszám-különbség között mérsékelt együtt járás tapasztalható $\left(r_{s}=0,354 ; p \leq 0,05\right)$. Az APM elővizsgálatban mért nyerspontszáma a Körök teszt fluencia mutatójának pontszám-különbségével mutatott gyenge, negatív irányú együtt járást $\left(r_{s}=-0,240 ; p \leq 0,05\right)$, a többi kreativitásmutató pontszámkülönbségével azonban nem korrelált szignifikánsan. Ered-ményeink szerint tehát, egy 9. évfolyamosok körében végzett vizsgálat alkalmával tapasztalt magas pszichometriai intelligencia a következő négy év várható intelligenciateszt pontszámbeli növekedését alig, a kreativitás-pontszámbeli változását pedig sehogy sem képes bejósolni. 
Végül a tanulók által nyújtott kreativitás- és intelligenciatesztbeli mutatók közötti pontszámkülönbségek egymással való korrelációs kapcsolatait is feltérképeztük. A pontszámkülönbségek közötti együtt járással kapcsolatban (vö.: 4. táblázat) az alábbiakat fogalmazhatjuk meg:

a) Egy kreativitásteszt különböző mutatóiban a két különböző időpontban történt mérés során tapasztalt pontszámkülönbségek pozitív korrelációs kapcsolatban állnak egymással ( $p \leq$ 0,05). E kapcsolat a verbális teszt esetében $\left(r_{s}=0,328-0,965\right)$ némileg erősebb, mint a figurális teszt esetében $\left(r_{s}=0,296-0,828\right)$. Mindkét tesztben a fluencia, az originalitás és a flexibilitás különbségváltozói mutatták a legerősebb korrelációt (Szokatlan használat teszt: $r_{s}$ $=0,907-0965 ;$ Körök teszt: $\left.r_{s}=0,738-0,837\right)$, tehát azok a változók, amelyek nyerspontszámai egymással is igen szoros kapcsolatban állnak. A relatív flexibilitás különbségváltozójával nem korrelált szignifikánsan mindkét teszt fluencia különbségváltozója, illetve a verbális teszt originalitás különbségváltozója. Általánosságban véve tehát: a valamely kreativitás mutatóban nagyobb pontszámkülönbséget elérő tanulók a mutatók függvényében $\mathrm{kb}$. 9-93\%-os valószínüséggel érnek el magas pontszámkülönbséget más kreativitás mutatóban is (ez alól a relatív flexibilitás és a fluencia, illetve a verbális teszt originalitás pontszáma jelent kivételt). A pontszámkülönbségek közötti korrelációk alakulása mintegy leképezi az egyes kreativitásmutatók közötti korrelációk alakulását.

b) A két kreativitásteszt mutatóinak pontszámkülönbségei között $r_{s}=0,307-0,636(p \leq 0,05)$ együtt járást tapasztaltunk. Az egyik kreativitástesztben nagyobb mértékü pontszám növekedést elérő tanulók kb. 9-36\%-os valószínüséggel értek el magasabb pontszám különbségeket a másik kreativitástesztben. A verbális és a figurális kreativitás mérsékelt együttváltozása mellett szóló eredmény jelzi, hogy e kétféle kreativitás nem teljesen független egymástól.

c) Arra is rákérdeztünk, hogy a kreativitástesztbeli és az intelligenciatesztbeli pontszámkülönbségek korrelálnak-e egymással. A Spearman-féle rangkorreláció-számítás eredménye szerint a két időpontban végzett kreativitásvizsgálatok során nagyobb pontszámbeli növekedést nyújtó tanulók, az intelligenciatesztekben is nagyobb valószínüséggel érnek el nagyobb pontszámbeli különbséget $\left(r_{s}=0,251\right.$ és 0,$\left.380 ; p \leq 0,05\right)$. Másképp: a pszichometriai kreativitás nagyobb mértékü fejlődése mérsékelt együtt járást mutat a pszichometriai intelligencia nagyobb mértékü fejlődésével. Az intelligencia és a kreativitás (pontszámkülönbségekkel jellemezhető) fejlődésének kapcsolata e két kognitív képességterület kölcsönhatását jelzi. E kölcsönhatás mérsékelt jellegét mutatja az az észrevétel is, hogy az APM intelligenciatesztben az elővizsgálat során magasabb (medián feletti) pontszámot elérő tanulók kizárólag a Körök teszt relatív flexibilitás mutatójának különbségváltozóját tekintve különböznek szignifikánsan az APM tesztben medián alatti pontszámot elérő diákoktól. A kreativitásmutatók különbségváltozóinak döntő többségében azonban nincs szignifikáns különbség a 14 éves kor körül felvett intelligenciatesztben medián alatti/feletti eredményt elérők között.

Mindent összevetve csak részben nyert igazolást az a feltételezés, hogy az intelligenciatesztben magasabb pontszámot elérők, jobb teljesítményt fognak nyújtani a kreativitástesztekben. Úgy tünik, hogy a pszichometriai intelligencia alapján a kreativitásmutatókban történő fejlődés bejóslása igen esetleges.

A nemek közötti különbségekre vonatkozó hipotéziscsoportunk - miszerint különbséget fogunk tapasztalni a lányok és a fiúk kreativitás tesztekben nyújtott teljesítménye terén és feltételezhetően a verbális kreativitás feladatokban a lányok lesznek eredményesebbek, a figurális feladatokban pedig a fiúk; és ez a különbség megmarad az életkor elörehaladásával nem nyert igazolást. A vizsgálat eredménye szerint a verbális kreativitásvizsgálat és az intelligenciavizsgálat esetében nincs szignifikáns különbség a nemek között. Mindez nem támasztja alá azokat a kutatásokat (Cambell, 1960; Simonton, 2004), melyek a nemek közötti 
különbségekre fókuszálnak. ha van szignifikáns nemek közötti különbség egyáltalán, akkor az ellentétes irányú a várthoz képest: a figurális Körök teszt bemeneti vizsgálatában a flexibilitás, a kimeneti vizsgálatában az originalitás, flexibilitás és átlagos originalitás esetében is a lányok értek el szignifikánsan $(p \leq 0,05)$ magasabb pontszámot. Így nem tudjuk alátámasztani azokat a kutatásokat (Halpern, 1986; Wynn, 1996), melyekben megállapították, hogy a nők verbalitás terén, a férfiak pedig a téri-, képi feladatok megoldásában eredményesebbek. A Körök teszt többi változójában nincs nemek szerinti különbség.

\section{Korlátok}

A tesztelés korlátjainak egy része azonos a longitudinális vizsgálatok általános problémájával, mely szerint előfordulhat, hogy a mintában lévő emberek hozzászoknak a különféle teszthelyzetekhez, azaz megtanulhatják, hogy milyen választ kell adniuk (Cole és Cole, 2003). Ennek következtében nehéz nyomon követni, hogy a személy válaszainak időbeli változásai a fejlődés eredményeként jelentek meg, vagy egyszerüen csak a tesztfelvételben szerzett gyakorlottság befolyásolta azt. Másrészt a jövőben érdemes lenne a kutatás eredményeit nagyobb mintán is ellenőrizni.

\section{Konklúzió}

A vizsgálat legközvetlenebb haszna, hogy korszerü adatokat szolgáltat az egyén személyes kreativitásának változására, illetve a pszichometriai kreativitás időbeli aspektusaira vonatkozóan. A személyes kreativitás változására vonatkozó eredmények segítséget nyújthatnak a kreativitás alapú tehetségbeválogató, azonosító vizsgálatokban. Eredményeink alapján megállapítható, hogy a bemeneti vizsgálatok bejósló jellege a kimeneti eredményekre vonatkozóan viszonylagos. Azaz nem lehet határozott véleményt mondani a gimnázium első éveiben mért kreativitás értékek alapján az érettségi környékén tapasztalt pszichometriai kreativitásra vonatkozóan; így a tehetséggondozó programokba való beválogatás során többszöri és legfőképp többféle (verbális és figurális) tesztek alkalmazása javasolt.

A kutatás közben azonban a teszthasználat számos problémájára is fény derült: 1) A hazai tesztadaptációk értékelési rendszere és sztenderdjei, nem az eredeti TTCT alapján készültek, ebből következően a magyarországi és a nemzetközi vizsgálatok eredményei nem minden esetben összehasonlíthatóak. 2) A hazai kreativitástesztek változatlan formában, felülvizsgálás nélkül kerülnek felhasználásra több mint negyed évszázada, holott a mintájukként szolgáló TTCT eredményeit azóta többször felülvizsgálták, revideálták. 3) A tesztfüzetben található válaszok elavultak, nem alkalmazkodnak a mai tanulók válaszaihoz (pl. pack-man, $\mathrm{X}$-Box, smiley). Mindezek megerösítették azon véleményünket, hogy szükségessé vált a hazai kreativitástesztek revideációja; melynek kutatási tapasztalatokon nyugvó megvalósítása folyamatban van.

\section{Irodalom}

Alpaugh, P.K., Birren, J. E.(1977). Variables affecting Creative Contributions across the Adult Life Span. Human Development, 20 (4.), 240-248.

Barkóczi I. (1976). Egyetemi hallgatók intelligenciájának és kreativitásának összefüggése produktivitásukkal és az ezekre vonatkozó oktatói ítéletekkel. Magyar Pszichológiai Szemle, 33, 5. 419-428.

Bereczkei T. (2003). Evolúciós pszichológia. Osiris Kiadó, Budapest. 
Cambell, D.T.(1960). Blind variation and selective retention in creative thought as in other knowledge process. Psychological Review, 67, 380-400.

Ceglédi E. (2009). A kreativitás és intelligencia szerepe az iskolai teljesítményekben. Letöltés ideje: 2015.09.01. Letöltés: http://folyoiratok.ofi.hu/sites/default/files/article_attachments/upsz_2009_11_05.pdf

Cole, M. és Cole, S. R. (2003). Fejlödéslélektan. Osiris Kiadó, Budapest.

Cramond, B., Mathews-Morgan, J., Bandalos, D. és Zuo, L. (2005). A report on the 40-year follow-up of the Torrance tests of creative thinking: Alive and well in the new millennium. Gifted Child Quarterly, 49. 283-291.

Cronbach, L.J. (1951). "Coefficient alpha and the internal structure of tests". Psychometrika 6 (3): 297-334

Cropley, A. (2000). Defining and measuring creativity: Are creativity tests worth using? Roeper Review, 23.72-79.

Csíkszentmihályi, M. (1996). Creativity: Flow and the psychology of discovery and invention. New York: HarperCollins.

Győri, J. (1986). Longitudinal study of divergent thinking abilities in school age children eight year follow up. Paper presented at Development European perspectives, Abstracts of Second European Conference on Developmental Psychology, Rome, Italy.

Helson, R. (1999). A longitudinal Study of Creative Personality in Women. Creativity Research Journal. 12.(2). 89-101.

Jones, H. E., Bayley, N. (1941). The Berkeley Growth Study. Child Development, 12, 167173.

Kang, C. (1989). Gender differences in Korean children's responses to the Torrance Tests of Creative Thinking from first to sixth grade. Unpublished master's thesis, University of Wisconsin, Madison, WI.

Kim, K. H. (2011). The Creativity Crisis: The Decrease in Creative Thinking Scores on the Torrance Tests of Creative Thinking. Creativity Research Journal, 23(4). 285-295. DOI: 10.1080/10400419.2011.627805

Kürti J. (1978). Az értelmi fejlödés tendenciái 6-14 éves korban. In 75 éves a Magyar Tudományos Akadémia Pszichológiai Intézete. Budapest. 245-253.

Kürti J. (1982). A kreatív képességek és az intelligencia fejlődését befolyásoló tényezők. Pszichológia, 2( 4.). 483-517.

Marcon, R. A. (1995). Fourth-grade slump: The cause and cure. Principal, 74.(5.), 16-17.

Moffitt, T. E., Gabrielli, W. F., Mednick, S. A., és Schulsinger, E (1981). Socioeconomic status, IQ, and delinquency. Journal of Abnormal Psychology, 90, 152-156.

Plucker, J. A. (1999). Is the proof in the pudding? Reanalyses of Torrance's (1958 to present) longitudinal data. Creativity Research Journal, 12. 103-114.

Plucker, J. A. (2000): Is the proof in the pudding? Reanalyses of Torrance's (1958 to present) longitudinal data. Creativity Research Journal, 12. 103-114.

Razumnikova, O. M., Tarasova, I. V. és Vol'f, N.V. (2009).Characteristics of cortical activity in persons with high and low verbal creativity: analysis of alpha1,2 rhythms. Zh Vyssh Nerv Deiat Im I P Pavlova, 59(5):581-606.

Razumnikova, O.M.(2009).The relationship between frequency-spatial parameters of the baseline EEG and levels of intelligence and creativity. Zh Vyssh Nerv Deiat Im I P Pavlova. 59(6):686-695.

Romaniuk J.G. és Romaniuk M. (1981).Creativity across the Life Span: a Measurement Perspective. Human Development, 24.366-381.

Runco, M. A. (1999). Time. In M. A. Runco, S. Pritzker (eds.). Encyclopedia of Creativity. CA: Academic. (Vol. 2). San Diego. 659-663. 
Runco, M. A., Millar, G., Acar, S., Cramond, B. (2011). Torrance Tests of Creative Thinking as Predictors of Personal and Public Achievement: A Fifty Year Follow-Up. Creativity Research Journal, 22 (4).

Salamon, J. (1982). Részben divergens és divergens materializált feladatmegoldás fejlődése. Magyar Pszichológiai Szemle, 3. 247-259.

Salamon, J. (1992). Figurális és verbális divergens feladatmegoldás longitudinális vizsgálata általános iskolai tanulóknál. Pszichológia, 12 (4.). 567-579.

Siegelman, C. K.és Rider, E. A. (2006). Life-Span Human Development. Thompson Learning. Madrid.

Simonton, D.K.(2004).Creativity in scienece: Chance, logic, genius and zeitgeist. Cambridge, England:Cambridge University Press.

Smith, G. J. W., és Carlsson, I. (1983). Creativity in early and middle school years. International. Journal of Behavioral Development, 6. 167-195.

Timmel, J. L. (2001). Creativity and acculturation: Psychological and cultural effects on the divergent thinking of cuban preadolescent immigrants entering the United States. Dissertation Abstracts International Section A: Humanities and Social Sciences, 61(9-A). 34-68.

Torrance, E. P. (1966). Torrance tests of creative thinking: Norms-technical manual. Personnel Press. Princeton.

Torrance, E. P. (1977). Creativity in the classroom. Washington, DC: National Education Association.

Torrance, E. P. (1980). Growing Up Creatively Gifted: The 22-Year Longitudinal Study. The Creative Child and Adult Quarterly, 3, 148-158.

Torrance, E. P. (1981a). Predicting the creativity of elementary school children (1958-80) and the teacher who "made a difference." Gifted Child Quarterly, 25.

Torrance, E. P. (1981b). Empirical validation of criterionreferenced indicators of creative ability through a longitudinal study. Creative Child and Adult Quarterly, 6, 136-140.

Torrance, E. P. (2002). The manifesto: A guide to developing a creative career. Ablex. Westport, CT.

Tóth L. (2011): A kreativitás mérésének módszerei. In: Münnich Á. (szerk.): A kreativitás többszempontú vizsgálata. Didakt Kiadó, Debrecen. 41-47.

Wynn, T. (1996). The evolution of tools and symbolic behavior. In Lock, A. J.; Peters, C. R. (Eds). Handbook of Symbolic Evolution. Clarendon Press, Oxford. 263-287.

Zétényi T. (2008). Kreativitás és inspekciós idő. Magyar Pszichológiai Szemle, 63. (4.) 677689.

Zétényi T. (2010). A kreativitás pszichometriája és a gondolkodás. Magyar Pszichológiai Szemle, 65 (2.), 233-242. 